Sajid Alfredo Herrera, "No que muera, sino que se arrepienta el criminal y viva. El

$\square$ LIBROS

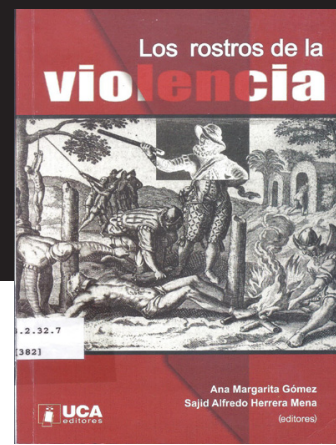

debate sobre el trabajo penitenciario en los

impresos salvadoreños, 1880-1900" en Ana

Margarita Gómez y Sajid Alfredo Herrera,

Los rostros de la violencia. Guatemala y Er

Salvador, siglos XVIII y XIX, San Salvador:

\title{
No que muera, sino que se arrepienta el criminal y viva. El debate sobre el trabajo penitenciario en los impresos salvadoreños, 1880-1900
}

La coyuntura de violencia social que experimenta el país debe llevarnos a reflexiones que vayan más allá de los análisis sincrónicos, no para señalar determinismos históricos y causalidades fatales, sino, por el contrario, para entender con mejores marcos explicativos las lógicas de las violencias en cuanto constructos culturales, elaborados a través de los tiempos, tanto desde "arriba" como desde "abajo". A partir de lo anterior, este ensayo busca responder a varias interrogantes: ¿Por qué los liberales salvadoreños decimonónicos creyeron que la pena de muerte no era la mejor solución para frenar la ola de crímenes y delincuencia que vivía el país en aquel siglo? ¿Cuáles fueron las posturas que legitimaron la creación de una penitenciaría nacional? ¿Era posible redimir a los delincuentes a través de un sistema penitenciario? ¿Bastaría este sistema para contener, "domeñar" y transformar conductas anómalas, sobre todo si sus resortes eran biológicos? ¿Cómo empezó a impactar en los medios intelectuales salvadoreños el positivismo criminológico?

Algunas de las anteriores interrogantes nos podrían parecer muy familiares en nuestros días. En efecto, el que nos preguntemos por la contención de la criminalidad, la pena de muerte o la idealización del sistema penitenciario forman parte de las opiniones, debates e imaginarios desplegados en diversos medios hoy en día por parte de diversos actores sociales. Ello nos indica, entonces, ciertas continuidades de problemáticas en el país. ¿Estaríamos hoy en día dispuestos a continuar fundamentando que la violencia social es producto de la guerra de doce años que vivió El Salvador, la cual terminó desmembrando el tejido social? O más bien, ¿Hubo un conjunto de prácticas y representaciones de la violencia que han sido construidas socialmente a través de nuestra historia? Los estudios historiográficos más recientes se inclinan a sugerir que las formas como los y las salvadoreñas pensaron en dirimir sus problemas, ante una ausencia, debilidad y/o ineficacia institucional, han sido a través del conflicto. Por supuesto que todavía hacen faltan muchos más estudios para poder estar seguros de lo anterior. De cualquier forma, los estudios realizados hasta ahora nos proporcionan importantes reflexiones que no debemos desdeñar a la hora de pensar ciertas políticas encaminadas a prevenir una "cultura de la violencia".

El ensayo en cuestión está basado en fuentes impresas de diversa índole: periódicos, revistas académicas y algunas leyes. A través de ellas el autor ha querido aproximarse al debate de los políticos y los académicos en torno a la necesidad, utilidad y eficacia de un sistema penitenciario en El Salvador, durante las últimas décadas del siglo XIX. El ensayo ha tenido una inspiración fundamental en la obra del filósofo francés Michel Foucault, quien ha trabajado el sistema penitenciario en la Francia del siglo XIX en su estudio clásico Vigilar y castigar. Pues bien, ante 
el deseo de los políticos y académicos salvadoreños de abandonar las prácticas inhumanas utilizadas para advertir, contener, prevenir o aniquilar a los individuos disfuncionales, el régimen penitenciario, de corte panóptico, se presentaba como una modélica alternativa. En lugar de aniquilar la vida de los delincuentes, se creyó que estos podían ser regenerados a través del trabajo remunerado al interior de las nuevas cárceles, tal como lo harían los individuos libres dentro de una sociedad liberal. No en vano Francisco Gavidia había advertido que el trabajo era una religión. Los políticos e intelectuales salvadoreños estaban, entonces, apostando por la vía de lo que ellos consideraron moderna: lejos que el Estado se ensañara contra la vida y el cuerpo de los criminales, la humanización del sistema punitivo salvadoreño generaría, a la larga, el progreso económico-social deseado. La modernidad liberal les avalaba cambiar el espectáculo de la muerte o los azotes, por el del trabajo edificante de vidas para el progreso del país.

El debate sobre el nuevo sistema punitivo en El Salvador decimonónico no sólo alcanzó las esferas civiles. También los periódicos de la Iglesia Católica intervinieron, advirtiendo la necesidad de influir decididamente al interior de la penitenciaría. Algo que probablemente no fue visto con buenos ojos por algunos políticos e intelectuales si consideramos que en las últimas décadas del siglo XIX se establecieron reformas que buscaron la separación del Estado y la Iglesia. De cualquier manera, la productividad de una "república cafetalera" necesitaba más brazos para el trabajo; algo que los políticos, productores, académicos y élites vieron que podía lograrse con los reglamentos contra vagos y ociosos y la creación de un sistema carcelario que convirtiera a los disfuncionales en hombres honrados. Necesitaríamos de otros estudios para calibrar hasta cuándo llegó este convencimiento e idealización del sistema penitenciario en el país. Al menos, en el caso francés estudiado por Foucault, muchos ciudadanos se dieron cuenta muy pronto que el régimen panóptico se había transformado en una escuela de delincuentes. De allí que valdría la pena preguntarnos qué tantos frutos ha proporcionado este régimen en El Salvador, nacido dentro de una lógica liberal, capitalista y disciplinaria.

El ensayo finaliza analizando los primeros debates sobre la delincuencia bajo los argumentos del positivismo criminológico. La influencia en América Latina de esta corriente de pensamiento penal, que se movió dentro de marcos interpretativos sustentados en la biología, fue muy fuerte a partir del siglo XIX. El estereotipo del criminal nato, con rasgos anatómicos determinados o con vicios específicos (prostitutas y alcohólicos), se constituyó en parte de una agenda científico-penal que comenzó a plantearse en el país en revistas académicas de finales de siglo. Trabajos recientes, dedicados al siglo XX, dan cuenta cómo estos debates académicos generados una centuria previa fueron decisivos en la construcción de políticas anti-delincuenciales. Fueron decisivos, asimismo, en la continuidad del racismo y la exclusión social. De ahí que uno de los objetivos del ensayo en cuestión ha sido proponer algunos caminos de investigación historiográfica que intenten mostrar las continuidades y rupturas en torno a los imaginarios y prácticas de la violencia, así como la capacidad de contenerlas o reprimirlas por parte del Estado u otras instituciones.

Sinopsis a cargo de Sajid Alfredo Herrera Director Nacional de Investigaciones en Cultura y Arte Secretaría de Cultura de la Presidencia. 